\title{
Garlic and onion sensitization among Saudi patients screened for food allergy: a hospital based study
}

\author{
*Almogren $\mathrm{A}^{1}$, Shakoor $\mathrm{Z}^{1}$, Adam $\mathrm{MH}^{2}$ \\ 1. Department of Pathology, College of Medicine and University Hospitals, King Saud University, Kingdom of Saudi \\ Arabia \\ 2. Department of Pathology, King Khalid University Hospital, King Saud University, Kingdom of Saudi Arabia
}

\begin{abstract} test (RAST) using Pharmacia ImmunoCAP 250 analyzer. coexisting specific IgE antibodies against garlic and onion. and allergenic potential of these food materials.

\section{Introduction}

Food allergy is an adverse immunological response to ingested foods especially the proteins. ${ }^{1}$ A number of studies have identified foods most frequently involved in allergic reactions. Among children in the United States the most common food allergies are due to eggs, cow's milk, peanuts, tree nuts, soy, wheat, fish, and shellfish whereas in adults peanuts, tree nuts, fish and shellfish are frequently implicated. ${ }^{2-}$ ${ }^{5}$ There are however few studies investigating allergic reactions to some very commonly consumed foods such as garlic and onion that belong to the Liliaceae family of foods.
\end{abstract}

Background: Detection of specific IgE antibodies against food materials indicates allergic sensitization. Some very widely consumed foods materials such as garlic and onion have rarely been investigated for their allergenic potential.

Objectives: To assess the presence of garlic and onion specific $\operatorname{IgE}$ antibodies in patients investigated for food allergy. Methods: Radioallergosorbent test (RAST) results of 108 patients with clinical suspicion of food allergy who were specifically screened for garlic and onion specific IgE antibodies along with other food allergens were analyzed retrospectively at King Khalid University Hosptial between January 2008 and April 2009. This group of patients included 73 males and 35 females with mean age $27+13.2$ years. Estimation of garlic and onion specific IgE antibodies was performed by radioallergosorbent

Results: Out of the 108 patients $15(13.8 \%)$ had garlic and onion specific IgE antibodies in their sera. Garlic specific IgE antibodies with the RAST scores between one to four were present in 14 and onion specific IgE were detected in 13 patients. For garlic specific IgEs majority of patients (08) had RAST score of one (0.35-0.69 kU/L) and for onion specific $\operatorname{IgE}$ antibodies seven patients had RAST score of two (0.70-3.49 kU/L). Among these patients $12(80 \%)$ were found to have

Conclusion: The presence of garlic and onion specific $\mathrm{IgE}$ antibodies in a sizeable number of patients indicate sensitization

Key words: Food allergy, garlic, $\operatorname{IgE}$, Liliaceae, onion, radioallergosorbent test African Health Sciences 2013; 13(3): 689 - 693 http://dx.doi.org/10.4314/ahs.v13i3.24

\begin{tabular}{|l|}
\hline *Corresponding author: \\
Dr. Adel Almogren \\
Department of Pathology \\
College of Medicine and University Hospitals \\
King Saud Uninversity \\
P. O. Box. 2925 \\
Riyadh 11461 \\
Kingdom of Saudi Arabia \\
Phone: 00966-1-4671843 \\
Cell: 0506252756 \\
E-mail: almogren@ksu.edu.sa \\
\hline
\end{tabular}

African Health Sciences Vol 13 Issue 3 September 2013
Apart from garlic and onion, asparagus and leek are the other members of the Liliaceae family. Allergenic cross-reactivity has been detected not only among the members of Liliaceae family ${ }^{6}$ but also between the members of this family and grass pollens. ${ }^{7}$ The Lilaiceae vegetables have been shown to be capable of inducing contact sensitization ${ }^{8,9}$ to an extent that in some countries garlic is being considered next to nickel as an allergen inducing allergic contact dermatitis. ${ }^{10}$ Members of Liliaceae family also induce immediate IgE-mediated reactions and among them once again garlic has been shown to be a potent inducer of specific $\operatorname{IgE}$ antibodies in the patients. ${ }^{11}$ There are however only few case reports of raw asparagus causing IgE-mediated contact urticaria. ${ }^{12}$ and occupational rhinitis and asthma. ${ }^{13}$ IgE-mediated food allergy due to cooked asparagus ingestion has also been described. ${ }^{14}$

In the presence of history suggestive of food allergy the diagnosis is usually made by estimation of food specific $\mathrm{IgE}$ antibodies, skin prick test and standardized food challenge. ${ }^{15} \mathrm{IgE}$ mediated reactivity to food proteins is considered to be a key 
factor mediating inflammatory process in about one third of patients with refractory allergic dermatitis. ${ }^{16}$ Measurement of food specific IgE antibodies has already been proposed to be a useful tool for identification of patients who are more likely to react to certain foods and develop clinical signs and symptoms. ${ }^{17}$

This study in retrospect examines quantitative assessment of specific $\mathrm{IgE}$ against garlic and onion among patients screened for the presence of food allergy.

\section{Methods}

\section{Study population}

During the period between January 2008 and April 2009 RAST results of 108 Saudi patients irrespective of their age and gender who were screened specifically for garlic and onion specific $\operatorname{IgE}$ antibodies along with other food allergens were analyzed retrospectively at King Khalid University Hospital, King Saud University, Riyadh. This group of patients included $73(67.5 \%)$ males and $35(32.5 \%)$ females with the mean age $27+/-13.2$ years. The number of patients either equal to or less than 18 years was 27 (25\%). The indications for requesting the RAST were gastrointestinal disturbances following food ingestion where the main complaints were abdominal cramps, urticaria, contact dermatitis, rhinitis and asthma. allowed to react for 30 minutes at $37^{\circ} \mathrm{C}$. After incubation unbound enzyme-anti-IgE was washed away and the bound complexes were incubated with developing agent (4-methylumbelliferyl-beta-Dgalactoside) for 10 minutes. During this time the substrate got cleaved and the fluorescing product 4 metylumbelliferon was released. The reaction was then stopped by adding stop solution. Test response was detected by measuring the fluorescence of the elute. The calibration range for specific $\operatorname{IgE}$ was from 0.1 to $100 \mathrm{kU} / \mathrm{L}$. Result was obtained by transforming the response for the patient samples to concentrations in $\mathrm{kU} / \mathrm{L}$ (kilounits per liter) using the calibration curve. Values lower than $0.35 \mathrm{kU} / \mathrm{L}$ were considered negative. Table 1 shows the interpretation of RAST score from 0 to 6 based on quantitative assessment of the specific $\operatorname{Ig} \mathrm{E}$ in $\mathrm{kU} / \mathrm{L}$.

\section{Results}

Out of the total 108 patient records included in the study $15(13.8 \%)$ patients were found to have garlic and onion specific $\mathrm{IgE}$ antibodies. Among them there were 9 males and 6 females. This group of patients included 5 patients with urticaria, 5 with gastrointestinal symptoms, 3 with contact dermatitis and 2 patients with asthma (data not shown).

Figure 1 shows the concentration of allergen specific IgE based on RAST scores. Majority of the

Table 1: Interpretation of RAST scores based on quantitative assessment of specific IgE concentration

\begin{tabular}{lllllllc}
\hline RAST Test Score & 0 & 1 & 2 & 3 & 4 & 5 & 6 \\
\hline Concentration of specific & $<0.35$ & $0.35-0.69$ & $0.70-3.49$ & $3.5-17.49$ & $17.50-49.99$ & $50-100$ & $>100$ \\
$\operatorname{IgE}(\mathrm{kU} / \mathrm{L})$ & & & & & & & \\
\hline
\end{tabular}

RAST $=$ Radioallergosorbent test. The ImmunoCAP test demonstrates patient sensitivity to specific allergens in number of kilounits per liter (kU/L).

\section{Measurement of specific IgE}

Assessment of allergen specific IgE for garlic and onion was performed by radioallergosorbent test (RAST) using Pharmacia ImmunoCAP 250 analyzer (Phadia, Uppsala, Sweden) in accordance with the recommendations of the manufacturers. Briefly, serum samples were dispensed in cups containing allergen covalently coupled to ImmunoCAP which is a cellulose derivative. Following incubation for 30 minutes the excess of sample was removed by the machine. Enzyme (alpha-galactosidase generating a fluorescent cleavage product)-labeled anti- $\operatorname{IgE}$ antibodies were added and the contents were patients (08) with garlic specific IgE had a RAST score of $1(0.35-0.69 \mathrm{kU} / \mathrm{L})$ of the antibody followed by 3 with a RAST score of 3 (3.5-17.49 $\mathrm{kU} / \mathrm{L})$, two with RAST score of 2 (0.70-3.49 kU/ L) and one had a RAST score of 4 (17.5-49.99 kU/ $\mathrm{L})$ of garlic specific $\mathrm{IgE}$ antibodies. With regards to onion specific IgE antibodies seven patients had RAST score $2(0.70-3.49 \mathrm{kU} / \mathrm{L})$ of onion specific $\mathrm{IgE}$ antibodies followed by three patients with RAST score of $1(0.35-0.69 \mathrm{kU} / \mathrm{L})$, two patients with RAST score 3 (3.5$17.49 \mathrm{kU} / \mathrm{L})$ and one patient with the RAST score of 4 $(17.50-49.99 \mathrm{kU} / \mathrm{L})$ for onion specific IgE antibodies. 


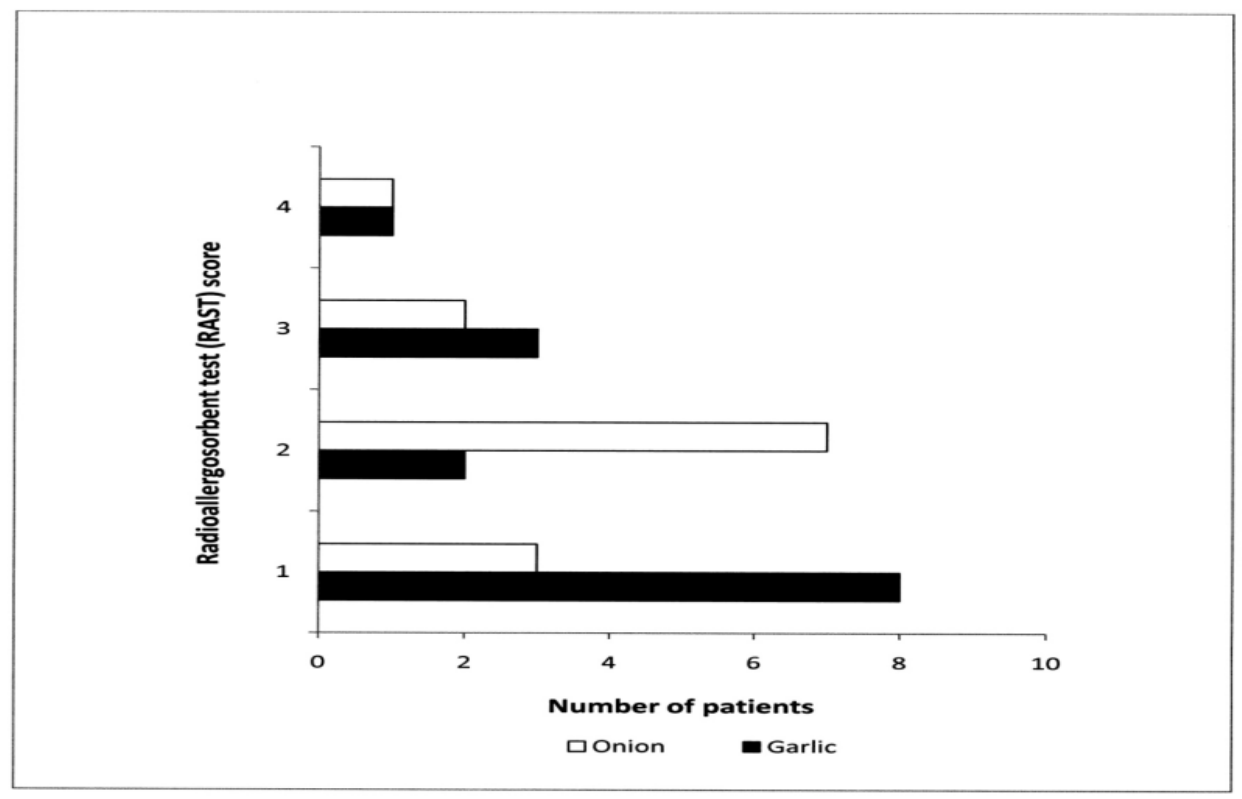

Figure 1: Assessment of garlic and onion specific IgE antibodies in Saudi patients with clinical suspicion of food allergy $(n=15)$

Table 2 shows data for distribution of both garlic and onion specific IgE antibodies in patients. Out of the total 15 patients where allergen specific $\operatorname{IgE}$ antibodies were detected 12 patients had co-existing garlic and onion specific $\mathrm{IgE}$ antibodies. Two patients had only garlic specific IgE antibodies and one had $\operatorname{IgE}$ antibodies against onion only. The severity of symptoms in various disorders that patients were suffering from did not reveal any association with the RAST scores.

Table 2: Distribution of garlic and onion specific IgE antibodies among patients with various allergic disorders $(n=15)$

\begin{tabular}{llc}
\hline $\begin{array}{l}\text { Allergen } \\
\text { specific IgE }\end{array}$ & $\begin{array}{l}\text { Number of } \\
\text { patients }\end{array}$ & Percentage \\
\hline Garlic and onion & 12 & 80 \\
$\begin{array}{l}\text { co-existence } \\
\text { Garlic only }\end{array}$ & 02 & 13.3 \\
Onion only & 01 & 6 \\
\hline
\end{tabular}

\section{Discussion}

Although with relatively low RAST scores in the majority of the individuals garlic and onion specific $\mathrm{IgE}$ antibodies were present in $13.8 \%$ of the patients investigated in the present study. Data regarding the prevalence of specific IgE antibodies against Liliaceae vegetables in patients with allergic disorders are lacking particularly in Saudi population. Detection of sensitization to Liliaceae vegetables by skin prick test however has shown that $4.6 \%$ of children and $7.7 \%$ of adults react to garlic, onion and chive ${ }^{18}$ thus providing an indirect evidence for the presence of $\mathrm{IgE}$ antibodies against Liliaceae family of vegetables. In the present study the data were obtained from patients with clinical suspicion of food allergy and can therefore be subjected to criticism on the basis of selection bias and may not represent the actual prevalence in general public.

Allergy to garlic can manifest in different forms. Bronchial asthma due to occupational exposure to garlic dust was first reported in $1940^{19}$ and following that only isolated studies have investigated the role of garlic in airway allergy. ${ }^{20-22}$ Skin sensitization due to garlic exposure has ranked garlic among the most potent allergens capable of causing allergic contact dermatitis. ${ }^{23}$ Garlic hypersensitivity has also been described as a cause of urticaria. ${ }^{24}$ Furthermore, consumption of young garlic described as an unripe garlic plant whose bulb has not matured has been incriminated in causing anaphylactic reaction. ${ }^{25}$ As opposed to cooked garlic consumption of raw garlic has also been reported to induce sever anaphylaxis which was attributed to heat induced degradation of allergenic proteins present in raw garlic ${ }^{26}$. Though in small numbers the presence of specific $\mathrm{IgE}$ antibodies against garlic detected in the present study in a variety of allergic disorders is in agreement with the rather broad 
spectrum of garlic related clinical manifestations of allergic disorders.

Despite the large scale consumption of onions, IgE mediated food allergy to onion has rarely been documented. Majority of the patients in the present study had RAST score 2 for specific $\operatorname{IgE}$ antibodies against onion. Similar level of specific IgE antibody against onion was detected in a case report of onion mediated analphylaxis ${ }^{27}$ indicating that the presence of very high absolute levels of specific $\mathrm{IgE}$ antibodies are not a prerequisite for life threatening $\mathrm{IgE}$ mediated reactions at least in the case of onion allergy. It is possible that the absolute levels of circulating allergen specific antibodies may not correlate well with the severity of clinical signs and symptoms. The density of the allergen specific IgE antibodies calculated as percent ratio to total $\mathrm{IgE}$ has been proposed to be a better measure for assessment and prediction of the severity of the clinical manifestations. ${ }^{28}$

Among the patients exhibiting RAST reactivity a high percentage $(80 \%)$ had specific $\operatorname{IgE}$ antibodies for both garlic and onion indicating high level of cross reactivity among the two members of Liliaceae family of vegetables. Using RAST inhibition assay allergenic extracts from onion and asparagus have been shown to successfully inhibit garlic RAST assay providing scientific evidence for the existence of cross reactivity among the members of Liliaceae family. ${ }^{21}$ However in another study asparagus was shown to significantly inhibit onion RAST reactivity whereas asparagus RAST was partially inhibited by onion. ${ }^{6}$ The observed discrepancy was explained by the presence of a smaller amount of common allergenic content in onion compared to asparagus. It would be however interesting to further investigate the cross reactivity of Liliaceae family by correlating the presence of the allergen specific $\operatorname{IgE}$ antibodies in blood with skin reactivity.

\section{Conclusion}

The presence of garlic and onion specific $\operatorname{IgE}$ antibodies in a substantial number of patients screened for food allergy indicate the allergenic potential of these food materials. This being a retrospective study was limited by lack of a control group of otherwise healthy asymptomatic individuals for comparative analysis. The observations of the present study however reveal that a sizable number of Saudi patients were sensitized against garlic and onion. This may have an important bearing in patients with allergies as both the vegetables are almost integral part of daily meals and are being infrequently investigated. Large scale investigations are recommended to further elucidate their role in allergic disorders in general a particularly in food allergy.

\section{References}

1. Sicherer SH, Sampson HA. Food allergy. J Allergy Clin Immunol 2006;117: S470-475.

2. Venter C, Pereira B, Grundy J, Clayton CB, Roberts G, Higgins B, et al. Incidence of parentally reported and clinically diagnosed food hypersensitivity in the first year of life. J Allergy Clin Immunol 2006; 117: 1118-24.

3. Venter C, Pereira B, Grundy J, Clayton CB, Arshad SH, Dean T. Prevalence of sensitization reported and objectively assessed food hypersensitivity amongst six-year-old children: a population-based study. Pediatr Allergy Immunol 2006; 17: 356-63.

4. Sicherer SH, Munoz-Furlong A, Sampson HA. Prevalence of seafood allergy in the United States determined by a random telephone survey. $J$ Allergy Clin Immunol 2004; 114: 159-65.

5. Bock SA, Atkins FM. Patterns of food hypersensitivity during sixteen years of doubleblind, placebo-controlled food challenges. $J$ Pediatr 1990; 117: 561-7.

6. Sanchez-Hernandez MC, Hernandez M, Delgado J, Guardia P, Monteseirin J, Bartolomé $\mathrm{B}$, et al. Allergenic cross-reactivity in the Liliacee family. Allergy 2000; 55: 297-9.

7. Boccafogli A, Vicentini L, Camerani A, Cogliati P, D’Ambrosi A, Scolozzi R. Adverse food reactions in patients with grass pollen respiratory disease. Ann Allergy 1994; 73: 301-8.

8. Lautier R, Wendt V. Contact allergy to Alliaceae. Case report and literature review. Derm Beruf Umwelt 1985; 33: 213-5.

9. Van Hecke E. Contact allergy to onion. Contact Dermatitis 1977; 3: 167-8

10. Lembo G, Balato N, Patruno C, Auricchio L, Ayala F. Allergic contact dermatitis due to garlic (Allium sativum). Contact Dermatitis 1991; 25: 330-1.

11. Falleroni AE, Zeiss CR, Levitz D. Occupational asthma secondary to inhalation of garlic dust. $J$ Allergy Clin Immunol 1981; 68: 156-60.

12. Sánchez MC, Hernández M, Morena V, Guardia P, González J, Monteiserín J, et al. Immunologic 
contact urticaria caused by asparagus. Contact Dermatitis 1997; 37: 181-2.

13. Eng PA, Yman L, Maaninen E, Wuthrich B. Inhalant allergy to fresh asparagus. Clin Exp Allergy 1996; 26: 330-4.

14. Escribano MM, Munoz-Bellido FJ, Serrano P, de la Calle A, Conde J. Acute urticaria after ingestion of asparagus. Allergy 1998; 53: 622-3.

15. Eigenmann PA, Calza AM. Diagnosis of IgEmediated food allergy among Swiss children with atopic dermatitis. Pediatr Allergy Immunol 2000;11: 95-100.

16. Eigenmann PA, Sicherer SH, Borkowski TA, Cohen BA, Sampson HA. Prevalence of IgEmediated food allergy among children with atopic dermatitis. Pediatrics 1998; 101(3):E8.

17. Sampson HA, Ho DG. Relationship between food-specific $\mathrm{IgE}$ concentrations and the risk of positive food challenges in children and adolescents. J Allergy Clin Immunol 1997; 100: 44451.

18. Moneret-Vautrin DA, Morisset M, Lemerdy P, Croizier A, Kanny G. Food allergy and IgE sensitization caused by spices: CICBAA data (based on 589 cases of food allergy). Allerg Immunol 2002; 34: 135-40.

19. Henson GE. Garlic: an occupational factor in the etiology of bronchial asthma. J Fla Med Assoc 1940; 27: 86.

20. Senri M, Taivanen A, Ruoppi P, Tukiaimen H. Three cases of occupational asthma and rhinitis caused by garlic. Clin Exp Allergy 1993; 23: 10114.
21. Lybarger JA, Gallagher JS, Pulver AW, Litwin A, Brooks S, Bernstein L. Occupational asthma induced by inhalation and ingestion of garlic. $J$ Allergy Clin Immunol 1982; 69: 448-54

22. Añibarro B, Fontela JL, De La Hoz F. Occupational asthma induced by garlic dust. $J$ Allergy Clin Immunol 1997; 100: 734-8.

23. Jappe U, Bonnekoh B, Hausen B M, Gollnick H. Garlic related dermatoses: case report and review of the literature. Am J Contact Dermat 1999: 10: 37-39.

24. Asero R, Mistrello G, Roncarolo D, Antoniotti PL, Falagiani P. A case of garlic allergy. J Allergy Clin Immunol 1998; 101: 427-428.

25. Pérez-Pimiento AJ, Moneo I, Santaolalla M, de Paz S, Fernández-Parra B, Domínguez-Lázaro AR. Anaphylactic reaction to young garlic. Allergy 1999; 54: 626-9.

26. Ma S, Yin J. Anaphylaxis induced by ingestion of raw garlic. Foodborne Pathog Dis 2012; 9: 773775 .

27. Arena A, Cislaghi C, Falagiani P. Anaphylactic reaction to the ingestion of raw onion. A case report. Allergol Immunopathol 2000; 28: 287-9.

28. Crimi E, Voltolini S, Minale P, Falagiani P. Value of immunoglobulin-E density in predicting nasal and bronchial response to inhaled allergens in rhinitic and asthmatic subjects with multiple sensitizations. Clin Exp Allergy 1999; 29: 166370. 